\title{
MEMÓRIAS DE UMA GERAÇÃO DA UTOPIA, OU DA ESPERANÇA COMO PRINCÍPIO
}

\author{
Benjamin Abdala Junior \\ (Universidade de São Paulo)
}

\begin{abstract}
RESUMO
A geração da utopia, de Pepetela, é um romance autoficcional: o narrador disserta ficcionalmente a partir de fatos e da ambiência diretamente vividos pelo autor. São problematizadas, em cada momento do processo da luta de libertação nacional de Angola, as reais motivações dos revolucionários, antes e depois da independência do país. Os revolucionários se motivaram por uma perspectiva ampla de libertação, para além da nacional: a social. Entretanto, como em toda a travessia, o ponto atingido na outra margem não foi exatamente o sonhado. $\mathrm{E}$ as formas opressivas do colonialismo acabaram por enredar, com novas roupagens, a Angola liberta, dando origem a perspectivas distópicas, contrárias à utopia revolucionária.
\end{abstract}

PALAVRAS-CHAVE: Utopia e distopia, libertação e colonialidade, potencialidade subjetiva e revolução

\section{ABSTRACT}

A Geração da Utopia, by Pepetela, is an autofictional novel: the narrator fictionally lectures from facts and ambience directly experienced by the author. The real motivations of revolutionaries before and after the country's independence are problematized in every moment of the process of national liberation struggle in Angola. The revolutionaries were motivated by a wide perspective of liberation, beyond the national level: the social. However, as in all crossings, the point reached on the other side was not exactly the one in their dreams. And the oppressive forms of colonialism ended up entangling, with new clothing, the free Angola, creating dystopian perspectives, contrary to revolutionary utopia.

KEYWORDS: utopia and dystopia, liberation and colonialism, potential subjective and revolution 
O leitor de A geração da utopia, de Pepetela, pode se surpreender com a primeira frase do romance: "Portanto, só os ciclos eram eternos”. Na verdade, essa afirmativa permite compreender vários aspectos das estratégias narrativas desenvolvidas no romance. É de grafar, para nossa apresentação/discussão, o "portanto", deslocado de sua função tradicional, que aponta para a conclusão de um enunciado, para a de introdutor da enunciação que se inicia. E também o fato de os ciclos já não serem eternos ("eram eternos", afirma o escritor), deslocados, assim, de sua significação tradicional. A razão da introdução do "portanto" é esclarecida de imediato. Ao responder a uma questão de um professor certamente tradicionalista e desconhecedor da oralidade angolana, o futuro escritor iniciou sua resposta com um "portanto", no que foi criticado. Não apenas ele, mas também o registro linguístico da oralidade dos angolanos.

Veio dessa situação a promessa que o autor fez a si mesmo de um dia começar um livro iniciando-o com essa palavra. Não se trata de apenas uma "vingança", como o escritor explicita com humor, mas - poderíamos acrescentar - de um modelo de articulação do pensamento que ele levará para as múltiplas esferas de sua práxis na vida social. Um modo crítico de pensar a realidade orientado contra o que pudesse se configurar como formulações autoritárias, próprias de atores sociais que detêm poder em suas múltiplas formas. Neste caso, poder simbólico, exercido graças às assimetrias de quem se coloca no papel tradicional de professor, valendo-se ainda das assimetrias culturais impostas pelo colonialismo.

Poderíamos ainda acrescentar: "portanto", em nível dessa oralidade do escritor, é uma conjunção que não se atém apenas à idéia de conclusão definitiva de um raciocínio, mas também à idéia de enlace, próprio do conectivo, que liga processos. E será com os olhos processuais, em que nada é definitivo, que os ciclos já não podem ser vistos como eternos. Isto é, fechados, repetitivos. Em seus vaivéns, eles não se repetem, mas incorporam a diversidade originada em seus volteios, para se abrirem aos novos tempos. Isto é, no desenho que estabelecem, acabam por configurar espirais, que se abrem para o futuro, não voltando ao ponto de partida. E será por essas fendas que impossibilitam o desenho do círculo que se configurará o espaço para a materialização das aberturas utópicas.

\section{AS ASAS DA UTOPIA E AS CONFIGURAÇÕES DA FORMA}

A utopia foi entendida pela geração do Pepetela como processo, de maneira a criar espaços para a configuração de perspectivas avessas às repetições ritualísticas dos ciclos. Embala-a motivações e inclinações de aberturas para um futuro, em construção desde o presente, com os pés no chão. Não a utopia que aponta sempre para um depois, mas para um agora que deve começar a se materializar. Uma utopia concreta, não abstrata, como se explicita logo no início do romance nos gestos de Sara, uma de suas personagens centrais, que em Lisboa se maravilha com o raiar de um 
dia luminoso: “[...] o Sol nascera num céu tão azul que até doía não poder voar. Sara abriu os braços descobertos. Inútil, não nascera pássaro" (PEPETELA, 1992, p. 46).

E, como "não nascera pássaro", Sara, como sua geração, vai procurar construir simbolicamente instrumentos para voar. O grande problema que se coloca em toda a trajetória dessa geração é a sobrevivências de formas antigas. Se por um lado elas são portadoras de experiências acumuladas, por outro acabam por se vincular, na prática, a formas de poder muitas vezes contrárias aos desejos de seus atores. Nas revoluções, como se explicita na fala de uma das personagens do romance, há um primeiro momento de euforia, contraditada pelo que se segue. Diríamos nós, um primeiro momento de fulguração utópica, quando o futuro sonhado parece se configurar no presente, mas na sequência a administração do país acaba consumindo esse desejo de mudanças em formas antigas. Formas políticas, econômicas e sociais, como também dos próprios atores sociais, que acabam por terem seus rostos modelados pela incorporação de máscaras sociais, que os levam ao exercício de papéis à maneira antiga.

Os bons ventos dessa geração vinham das perspectivas libertárias que sopravam, sobretudo, desde o final da Segunda Grande Guerra, respaldados nos princípios de autodeterminação dos povos da Carta da ONU. Não apenas esses ventos mais gerais, associados a dimensões políticas mais abrangentes, motivavam essa geração. Em plena Guerra Fria, a geração identificava-se com tendências socialistas e o sentido libertário, alargando-as com ventos mais novos da revolução dos jovens, que se inclinavam a uma revolução mais ampla. Libertação nacional, de um lado, mas também simultaneamente social, no caso dos países africanos colonizados por Portugal. O sonho era de construção de um "homem novo", como se dizia, sem as amarras que os aprisionavam a um mundo de formas vazias, que não mais se justificavam.

Esse ideário revolucionário marcou a vida política, com matizes diferentes, em muitas partes do mundo, dos anos de 1950 aos anos de 1970. No caso de Angola, como dos demais países africanos colonizados por Portugal, ao caráter nacional dessa luta anticolonial veio somar-se esse sentido de libertação social, através de seus principais movimentos revolucionários. Mais, como não havia uma nação, mas uma divisão arbitrária entre os povos africanos estatuída pelo colonialismo europeu desde o século XIX (Tratado de Berlim), tratava-se também de construir uma nação, integrando esses povos num mesmo estado. Projeto complexo, sobre o qual Pepetela disserta ficcionalmente em A geração da utopia, a partir do processo histórico que ele não apenas testemunhou, mas o vivenciou diretamente.

\section{ENTRE MELANCOLIA E ALEGRIA, UM TIRO PELA CULATRA}

Um primeiro marco simbólico dessa trajetória, problematizada pelo romance foi a CEI - Casa dos Estudantes do Império, de Lisboa (ha- 
via a de Coimbra). Criada pelo regime ditatorial de Antonio de Oliveira Salazar, para formar uma elite intelectual africana afinada com os valores autoritários da metrópole colonial, não logrou conseguir esse objetivo. Ao contrário, a Casa foi um grande núcleo organizador de resistência política, contribuindo para a formação dos movimentos independentistas, sobretudo a partir dos finais da década de 1950, e acabou por ser fechada, após um período de asfixia, em 1965.

Nos anos de 1950, os estudantes da CEI participavam de atividades contra a ditadura salazarista, ao lado dos portugueses. No final da década, entretanto, acabou por ocorrer uma inclinação diferenciada dos africanos para as lutas de libertação nacional, o que não foi bem compreendido pelos militantes portugueses, como registrado em $A$ geração da utopia. Não serão apenas essas as diferenças entre Angola e Portugal registradas por Pepetela, como o leitor poderá verificar. Um dos traços marcantes da cultura angolana, que já se explicitava, é a da alegria, contrastada com a melancolia portuguesa, visível, por exemplo, nas diferenças entre o batuque e o fado. Melancolia e alegria serão igualmente temas problematizados no curso do romance, envolvendo inclusive atores de Angola.

Foi nessa ambiência, para além dos almoços, jantares e festas estudantis, em que se desenvolve a efabulação do romance, que se publicaram textos de autores africanos, como os dos poetas angolanos Viriato da Cruz, Agostinho Neto e Antônio Jacinto. Foram nomes ativos do setor editorial da CEI Carlos Ervedosa, Costa Andrade, Ilídio Cruz, Alfredo Margarido e Fernando Mourão. Este último veio a fundar, depois, o Centro de Estudos Africanos da Universidade de São Paulo e, após a queda da ditadura portuguesa e concomitante libertação do jugo colonial, a primeira coleção de autores africanos em nosso país.

As interações entre as atividades da CEI com o nosso comunitarismo cultural foram amplas. E de maneira similar aos autores neorrealistas portugueses que olhavam para a literatura brasileira, também os estudantes africanos da CEI encontravam em nossa literatura e cultura (a música e a dança) ritmos e imagens mais próximos que os provenientes da metrópole colonial. Observe-se, nesse sentido, a fala de uma das personagens do romance:

- Vê o livro do Viriato da Cruz. Ele marca a ruptura definitiva com a literatura portuguesa. Utilização da voz do povo, na língua que o povo de Luanda usa. Já não tem nada a ver com tudo o anterior, em particular com os portugueses. A literatura à frente, expressar o pensamento popular de diferença. Os brasileiros fizeram isso há trinta anos. (PEPETELA, 1992, p. 77)

Viriato da Cruz, ao lado de poetas de sua geração, escreveu poemas com base em um português oralizado, com incorporações da língua quimbunda. 


\section{PÁTRIA, MÁTRIA E FRÁTRIA}

Se do ponto de vista simbólico o colonialismo obrigava os angolanos a verem Portugal como a pátria, não deixavam de situá-lo como poder paterno, profanador da terra africana. Na contraposição, identificavam-se com a cantada imagem da "Mamãe-África", adesão cada vez mais ativa à mátria de origem, que se fazia com os olhos na frátria brasileira, a ex-colônia que se libertou do colonialismo. São referências situadas no âmbito de nosso comunitarismo cultural e que chegam ao samba, de origem africana, e mesmo à prática desportiva, como as referências ao técnico brasileiro de futebol Otto Glória, que chegou a dirigir a seleção nacional portuguesa. Nesses tempos, que precedem os anos de chumbo da ditadura militar brasileira, deflagrada em abril de 1964, o olhar para o Brasil desenvolvimentista, da economia às manifestações literárias e culturais, inclusive no futebol (campeão do mundo em 1958 e, depois, em 1962), revestia-se de otimismo.

Num momento anterior ao tempo da efabulação do romance, cerca de dez anos antes, foram os estudantes politicamente ativos na CEI os futuros líderes dos movimentos de libertação nacional como Agostinho Neto, Amílcar Cabral, Mário Pinto de Andrade e Marcelino dos Santos. Eram eles os "Mais Velhos", que na perspectiva africana possuíam sabedoria. De forma organizada reivindicavam a autodeterminação de seus povos e se colocavam contra o fascismo português. Eram ainda posturas políticas não militares, possivelmente apoiadas pelo Partido Comunista Português, mas em face do autoritarismo e da repressão da ditadura portuguesa, foram obrigados a radicalizarem posteriormente suas posições, vindo a defender a luta armada.

Esses movimentos revolucionários africanos constituiram um dos lados da luta libertadora, afinada com perspectivas socialistas. Libertação nacional associada a uma libertação mais ampla, procurando criar o que se colocava nos eslogans revolucionários: um "homem novo". No caso de Angola, articuladas no MPLA - Movimento Popular de Libertação de Angola, estavam várias pequenas organizações, inclusive uma célula do Partido Comunista Português, nesse país. Não deixa de ser curioso o fato de esse partido metropolitano reproduzir a essa altura um esquema colonial, como se Angola fosse parte de Portugal (a chamada província ultramarina), deixando de viabilizar ou colaborar para a viabilização da constituição de um partido comunista autônomo em Angola.

Havia outras tendências entre as organizações políticas anticoloniais, associadas a perspectivas mais tradicionalistas, raciais, também registradas por Pepetela. Constituíam correntes que se atritavam com os horizontes socialistas da geração da utopia. O MPLA, para elas, era um partido de mulatos de Luanda, vistos negativamente. Não o viam como um movimento de cidadania angolana, onde entravam negros, brancos e mulatos. Do lado do colonizador, com a eclosão da luta armada, as questões 
raciais tornaram-se mais agudas em Portugal, acirrando a repressão, não só em Angola como também em Portugal.

Os argumentos para a crueldade indiscriminada da repressão da ditadura salazarista vieram da agressividade dos ataques da UPA (que deu origem posteriormente à FNLA e à UNITA). A postura portuguesa contrariava, assim, as teses lusotropicalistas da propaganda oficial salazarista, que procurava mostrar ao mundo que a colonização portuguesa foi sempre amorosa, amigável. Para tanto, serviu-se dos textos e da presença do brasileiro Gilberto Freyre em terras portuguesas, para quem os países africanos seriam parte do que denominou "mundo que o português criou", encobrindo o caráter agressivo e predatório dessa colonização, como aliás também ocorrera com outros colonialismos.

Como se vê, o fato de existir um agenciamento comunitário entre os países colonizados por Portugal não impede as assimetrias dos fluxos culturais e a existência de uma fração do campo intelectual propenso a justificá-las. Em relação ao Brasil escravista, na primeira metade do século $\mathrm{XX}$, a sociedade era vista por essa fração da janela da casa grande, uma óptica que não abarcava o fundamental do escravismo - a terrível situação do escravo do eito. De modo equivalente, já em meados desse século, esse olhar, denominado lusotropicalista, procurava não ver uma situação real de escravidão na África, denominada de forma eufemística como "contratados". Os "contratados" eram os novos escravos do século XX, autoritariamente obrigados ao exercício de um trabalho compulsório. O contratado foi tematizado pela geração da utopia, não apenas pela agressividade da exploração de seu trabalho, como na escravidão do século XIX, mas também pela sua condição de exilado. Neste poema, diretamente associado a essa geração da utopia, o "Mais Velho" Antonio Jacinto fala da separação amorosa e das impossibilidades da comunicação: "Eu queria escrever-te uma carta .../ Mas ah meu amor, eu não sei compreender/ por que é, por que é, por que é, meu bem/ que tu não sabes ler/ e eu - Oh! Desespero - não sei escrever também!”

\section{OS INTELECTUAIS E OS DESAFIOS DO PENSAMENTO UTÓPICO}

A perspectiva política intelectualmente dominante e que se mostrou mais consequente em relação à consecução de seus objetivos, como se observa em A geração da utopia, pautou-se por horizontes similares aos da personagem central do romance, Aníbal, o Sábio. Ele é o intelectual da revolução, um "fora de série", justamente por não se enquadrar nas formas ritualísticas que enredavam, tanto situações do passado quanto do presente. Nas estratégias discursivas do romance, permanece como um horizonte, que também não deixa de ser problematizado, sobretudo através de seu discurso com marcas autocríticas. Sua trajetória problemática acaba por ser historicamente simétrica à travessia dos sonhos libertários de sua ge- 
ração. Era partidário do MPLA, um partido de liderança de base citadina, socialista, voltado para o cidadão do país, da cidade e do campo, independentemente da cor da pele. Nesse percurso, que vai da luta política à luta político-militar, participam, na trama do romance, atores diferentes dele, contraditórios, mas que não deixavam de repetir os mesmos eslogans. Suas motivações, contraditórias, inclinavam-se a atitudes em desacordo com os sonhos libertários, e elas transparecerão nas oscilações de papéis que assumirão na trajetória do romance.

Importante a se destacar para o leitor é como tais caracteres contraditórios se atualizam, conforme a situação histórica do país. Quem se mostra oportunista numa determinada ambiência mais particularizada, vai depois atualizar essa forma de conduta em outras situações, inclusive quando assume poderes de estado. Se buscarmos identificações no sistema simbólico das populações rurais, o povo pode ser associado à árvore de Angola, e tais políticos desejam no fundo seus frutos, valendo-se da árvora para alcançá-los, como o leitor poderá verificar no romance. Embora as formas de conduta oportunísticas se repitam em configurações históricas diferentes, não configuram, entretanto, ciclos. Se o modo de pensar ou agir sobre o mundo aponta para desenhos equivalentes, o ciclo não se fecha.

Vem daí a necessidade de um horizonte de referência, como em Aníbal. Referência intelectual que faltará na Angola libertada do colonialismo, mas que mantém formas exclusivistas que preservam situações contra as quais lutou a geração da utopia. Em relação a esses horizontes colocam-se atores sociais que, no sentido positivo ou negativo, atualizam o desenho de seus gestos anteriores, procurando responder a cada nova situação colocada pela trama do romance. No sentido positivo, aqueles que têm conviç̧ões e integridade procuram preservar o sentido de seus gestos, como Aníbal. Se não podem fazê-lo numa dimensão mais larga, o fazem numa mais restrita a sua individualidade. Negativamente, o oportunismo das ações de determinados atores que pouco têm a ver com o ideário utópico. Inclinam-se eles para a preservação das formas antigas em proveito próprio, agora já em nível de poder. Para tanto, fazem pontes, que não deixam de ser irônicas, entre suas motivações individualistas e as solicitações hedonistas, narcisistas e competitivas da vida atual.

A atração pela modernidade do campo intelectual angolano foi importante para Agostinho Neto e sua geração, sem que desconsiderassem a alteridade em favor de modelos sintéticos. Modernização em todos os sentidos, da vida econômica à cultural, o que pressupunha um não retorno a formas de identidade afinadas com o tradicionalismo. Simbolicamente, era a afirmação do espaço de Luanda e não do campo. O grande desafio político, como aparece no romance, era traçar uma linha capaz de unir as diferenças entre cidade e campo num projeto consequente. Nos espaços de Luanda, havia não apenas aproximações e fricções entre contributos culturais de várias partes do interior do país, aceleradas pelas consequências da guerra. Havia ainda a presença do espaço exterior, como o horizonte da metrópole e da supranacionalidade comunitária. Um espaço de mes- 
clagens e também de tensões, consubstanciadas na literatura, miticamente situadas nos musseques, isto é, a cidade africana, em confronto com a cidade europeia. Essa mesclagem cultural, híbrida, contraditória, apontava, como se apercebe nos documentos do MPLA e nas produções literárias, para horizontes mais amplos, que abarcavam toda Angola, considerando as diferenças, mas sem os particularismos regionais que pudessem conduzir à desagregação política do país.

Essa era Angola, sob uma visão popular, construída pelo campo intelectual do país. E desse locus enunciativo, poder-se-ia acessar o mundo. Esta foi mais uma das aspirações dos intelectuais angolanos engajados na utopia revolucionária. Não deixava de ser uma aspiração, desde os tempos de formação dessa geração, que veio a conquistar a independência do país. As dificuldades do projeto apresentam-se de forma explícita ou subjacente no romance de Pepetela. Havia o desafio de muitas distâncias entre as regiões de Angola, como também da distância entre o próprio intelectual e o povo. Nos poemas dos "Mais Velhos" dessa geração, já se formulavam as dificuldades do projeto de identificação nacional. Há uma consciência da identificação que se faz nas manifestações culturais típicas, como na música, na dança e na culinária, mas o problema é de comunicação entre esses setores. Não obstante as dificuldades, para a geração da utopia a identificação existe, como se observa no poema "Mussunda amigo" de Agostinho Neto. Se de um lado a adesão de Mussunda (persona popular) salva o poeta do "abraço da jibóia" (o colonialismo), por outro ele se vê "escrevendo versos" que o amigo não entende. A solução para a diferença de situações será os dois caminharem juntos, olhando para horizontes correlatos, sob os embalos dos mesmos ritmos musicais, símbolo da angolanidade, que os identifica. Não deixa de ser um índice para os estudantes da CEI, a referência ao conjunto musical Ngola Ritmos.

O grande desafio desse campo intelectual, e como se apercebe na trajetória paradigmática de Aníbal, era comunicar-se com seu povo, dificuldade apontada acima por Agostinho Neto, que viria a ser apresentado, após a libertação colonial, como poeta e presidente da república. O problema continuou após a tomada de poder e, mais uma vez, o caminho de Aníbal, que detém simbolicamente a sabedoria, poderia ser exemplar para os demais participantes de sua geração. Diante dos descaminhos da revolução, ele se afasta para procurar se defender numa utopia mais pessoal. Faltou à revolução, entre muitos outros objetivos, a integração cidade e campo. Essa persona consegue individualmente e do ponto de vista simbólico uma forma de aproximação não apenas entre cidade e campo, mas também entre o intelectual e as aspirações populares. Mais do que o problema de comunicação linguística, que veio a ser resolvido por um vigoroso programa de alfabetização pelo governo revolucionário, colocam-se os emparedamentos coercitivos das formas políticas de poder, que mantêm correlação com as formas antigas contra as quais se lutou. Há muitas vezes entre elas uma simples operação de comutação de atores, preservando antigas assimetrias econômicas e sociais. 


\section{POTENCIALIDADE SUBJETIVA E DIALÉTICA DA ESPERANÇA}

Desenham-se nos versos de Agostinho Neto, como nos de Antonio Jacinto e Viriato da Cruz, o tema da utopia problematizado por Pepetela. Podemos entendê-la como a dialética da esperança, motivada pelo que poderíamos denominar potencialidade subjetiva de sua geração. No poema "Aspiração", Agostinho Neto carreia a energia utópica, em seu desejo de transformação. O título do poema já explicita essa inclinação da vontade do poeta. Diz Agostinho Neto, na primeira estrofe desse texto: "Ainda o meu sonho dolente/ e a minha tristeza/ no Congo, na Geórgia, no Amazonas"; e, nas três estrofes finais: "Ainda o meu sonho/ o meu grito/ o meu braço/ a sustentar o meu Querer/E nas sanzalas/ nas casas/ nos subúrbios das cidades/ para lá das linhas/nos recantos escuros das casas ricas/ onde os negros murmuram: ainda /O meu Desejo/ transformado em força/ inspirando as consciências desesperadas."

Os espaços da diáspora dos melancólicos "canto dolente" e "tristezas", transmudam-se em espaços de reivindicação na grande cidade simbólica da angolanidade. Observe-se que as palavras "Querer" e "Desejo" vêm grafadas com as iniciais em caixa alta. É a potencialidade subjetiva do sujeito poético a procurar dar voz contestatória aos homens dispersos, num espaço híbrido e conflituoso. As "consciências desesperadas" confluem, mesclando-se, de maneira a dar forma e força política ao projeto libertário do poeta. Atingir essa dimensão da potencialidade subjetiva, contribuindo para embalar o projeto libertário, com os pés fincados no chão angolano, é o sonho do poeta. Um sonho diurno de sua geração, traçado a partir das condições que entendiam ser as concretas do país. Um sonho diurno, sublinhamos, próprio da utopia concreta, estudada por Enst Bloch em sua obra maior - O princípio esperança.

Esta era a atmosfera dos jovens da CEI. Falar de utopia no romance de Pepetela significa problematizar a trajetória dessa geração que sonhava com um mundo diferente. Valendo-nos da conhecida imagem do mundo como travessias entre margens, a vida se faz para aqueles que têm a coragem de entrar nessas águas simbólicas, envolvendo-se entre correntezas que teimam em colocar obstáculos, com seus fluxos, de maneira a impedir a manutenção dos rumos do projeto traçado. Certamente, nas águas da vida, as múltiplas correntezas friccionam-se e quase sempre não se mostram direcionadas para o ponto desejado na outra margem. Este o desafio de uma travessia consciente. O horizonte utópico vislumbrado é o objetivo e, como costuma ocorrer, o ponto sonhado possivelmente não será atingido, em razão dos instáveis movimentos das águas que nos envolvem. A existência desses fluxos adversos pode não impedir a travessia, mas quase sempre acabam por deslocar o ponto de chegada. A travessia impõe riscos e há certamente a grande maioria das pessoas que recusa esses riscos e se coloca numa ponte, com o caminho e o objetivo rígido, preestabelecido, e vê a vida passar observando-a ritualmente à distância. Como afirmou Guimarães Rosa, o mundo do rio (existência vivida) não é o mundo da ponte... 
A geração é nomeada como utópica justamente porque se colocou nas águas do projeto revolucionário. Não sabiam ou minimizaram muitos de seus atores mais conscientes que, entre as dificuldades desses fluxos, estavam os caracteres dos próprios participantes do projeto. Atores sociais modelados pelas correntezas da situação anterior e compelidos a nelas ingressarem por razões muitas vezes alheias ou ainda próprias de seus caracteres. Por outro lado, não há identidades monolíticas, em termos individuais, de grupos sociais ou de nacionalidades. Somos marcados por caracteres múltiplos, eles próprios com hegemonias cambiantes, e as identidades devem ser vistas no plural. O romance tematiza a coerência desses atores sociais e suas ações mostram-se problemáticas, como o leitor se aperceberá desde o início do romance.

\section{NOVAS HEGEMONIAS E CONTINUIDADE DE HÁBITOS AUTORITÁRIOS}

Falamos anteriormente da abertura da espiral, tendo em conta o futuro. Para a geração da utopia de Pepetela, seria um caminho de apagamento dos valores individualistas para os sociais. Entretanto, as travessias podem inverter o sentido do movimento, levando os atores sociais ao afloramento de caracteres contextualmente inibidos, de sentido individualista. E não se trata só dos movimentos das águas da revolução, já que esses caracteres já estavam latentes na práxis cotidiana de muitos. Experiência social canalizada para a promoção do individualismo, e não do indivíduo em suas articulações de sentido social. E o pior, do ponto de vista coletivo, em razão da naturalização das formas conservadoras, são essas formas avessas à abertura do pensamento utópico da geração que acabam por serem mais facilmente aceitas. Em nível das formas de administração do poder e de sua aceitação coletiva.

Tal situação nos leva conceitualmente a falar em resistência das formas. Formas políticas, sociais, culturais e também a própria forma literária. Inovar radicalmente pode levar os atores sociais a falarem sozinhos. É necessária a política, para que a perspectiva sonhada ganhe abrangência, mas aqui ocorre um problema básico: se o ator, em função dessa política, se vê obrigado a usar máscaras anteriores de poder, se não tomar cuidado, acaba tendo sua face modelada por elas. É o problema das revoluções, como se vê em A geração da utopia. As concessões para garantir a governabilidade, em face de expectativas relacionadas às formas políticas anteriores, mostram-se conservadoras. E podem acabar por impossibilitar a concreção do horizonte sonhado e pelo qual os atores mais empenhados no ideário da geração consagraram suas próprias vidas.

Em Angola, a continuidade da guerra após a libertação colonial, agora guerra civil respaldada em interesses da Guerra Fria, fez com que houvesse uma militarização da administração do poder. Militarizaram-se todas as esferas de poder. Ironicamente, colocaram-se uniformes simbólicos 
até em manifestações populares, como até as festas carnavalescas. Nessa atmosfera, os intelectuais, aqueles capazes de apontar rumos, foram deixados de lado pelas correntezas da militarização, que levaram o ideal de uma sonhada plenitude para uma disciplina de caserna. Isto é, um emparedamento similar aos dos tempos coloniais. O desenho da truculência do colonizador, preservado agora, em novos atores e a ascensão de novos ricos, com os caracteres do capitalismo selvagem que a geração da utopia abominou.

A par dos gestos desses atores durante o processo registrado no romance, coloca-se aqui o problema das formas de administração política e econômica do novo estado e também das expectativas da própria população, que vê o mundo de acordo com os padrões estabelecidos. E, assim, o estado revolucionário acaba por se ver enredado pelas formas anteriores, mesmo procurando, em termos de discursos legitimadores (toda hegemonia procura legitimar-se), se desvencilhar das práxis coloniais. Para tanto, valeu-se, equivocadamente, das fórmulas de administração estatal do chamado socialismo real, que desconsiderava o fundamental para o pensamento utópico: a potencialidade subjetiva, presente nos quadros intelectuais, que ou se adequaram aos novos figurinos (até militares) ou foram colocados à margem do processo. Essa potencialidade subjetiva, avessa ao uniforme, presente na capacidade de agir criticamente sobre a realidade, constituía justamente a energia motora (utopia como manifestação do desejo) que ensejou a própria luta de libertação nacional e social. Era historicamente imprescindível se buscar novas formas de administração. Só que havia a evidência da guerra civil e a necessidade de não se correr riscos. $\mathrm{O}$ mundo da pretensa ponte (militarizada) a contornar os riscos de se entrar nas águas do rio.

\section{ABRAÇOS QUE SUFOCAM}

Em O cão e os caluandas, Pepetela criou a imagem de uma buganvília (a nossa primavera, que anuncia a renovação da estação), árvore que vai crescendo sobre as paredes de uma casa, e acabaria por destruí-la não fosse a ação desesperada de um cão já velho e sem forças, mesmo desdentado, que a arrancou pelas raízes. Os galhos da primavera, associada ao otimismo do renascimento das flores, são no fundo os abraços que sufocam. No caso, o próprio estado destruindo a casa angolana. Em A geração da utopia, numa perspectiva individual, das antigas motivações juvenis de Aníbal, aparecerá uma imagem, com desenho correlato, no capítulo "O polvo”. Os galhos da buganvília podem ser comutados pelos tentáculos do polvo, numa situação de conflito relativo aos desafios de sua individualidade, posterior à instalação do estado independente angolano.

As ações dos atores sociais de A geração da utopia pautam-se pela práxis, entendida em seu sentido ontocriativo: na medida em que pensamos/agimos sobre a realidade, vamos criando, de forma consciente ou não, determinados modos de articulação. E essas articulações migram de uma 
esfera do conhecimento para outra. Por exemplo, o consumismo que se estabelece em relação a mercadorias comercializáveis migra do campo econômico para outros da vida social. O romance não explicita essas relações, mas deixa-as evidente. As relações sociais se estabelecem conforme essa lógica, que no fundo é do capital. Fala-se inclusive o tempo todo, em nosso país, de capital intelectual. Evidentemente, as muitas esferas de atuação na vida sociocultural (inclusive cultura material) criam múltiplos modelos de articulação. Entretanto, tal amplitude não os deixam soltos, pois acabam por formar redes, nas quais os fios são costurados de acordo com as relações de hegemonia e subalternidade que eles estabelecem entre si.

Como toda hegemonia é porosa, já afirmamos, ela permite a emersão de outros caracteres, justamente para se legitimar, administrando sua diferença. Trata-se de uma forma de dinamizar o próprio sistema hegemônico. Somos individualmente e coletivamente múltiplos e uma visão crítica das implicações políticas desses caracteres (nível individual, nacional, social), verificará que eles se atritam e não deixam de se estabelecer essas hegemonias ou dominâncias. Na trajetória da geração e com certos atores do romance, tais caracteres que num momento são subalternizados afloram depois, sufocando a sociabilidade dos primeiros tempos. Como a própria enunciação reconhece, desde o primeiro capítulo, esses atores mostram atitudes que são no fundo oportunistas. Assim são os hábitos, que em suas linhas articulatórias impregnam as personagens do romance, mesmo em situações políticas que poderiam contraditá-los.

Observe-se, nesse aspecto, como se efetiva esse sentido articulador (modo de pensar a realidade) em outro romance de Pepetela, Mayom$b e$, escrito em plena guerrilha da luta de libertação nacional de Angola. O sentido crítico do narrador destaca linhas de articulação de hábitos, que impregnam suas personagens, deixando à mostra as reais motivações dos guerrilheiros, mitificados pelos discursos oficiais. Citemos uma personagem feminina, que de um ângulo periférico analisa a situação que experimenta entre os guerrilheiros:

Isso é que me enraivece. Queremos transformar o mundo e somos incapazes de nos transformar a nós próprios. Queremos ser livres, fazer a nossa vontade, e a todo momento arranjamos desculpas para reprimir nossos desejos. E o pior é que nos convencemos com as nossas próprias desculpas, deixamos de ser lúcidos. Só covardia. É medo de nos enfrentarmos, é um medo que nos ficou dos tempos em que temíamos a Deus, ou o pai ou o professor, é sempre o mesmo agente repressivo. Somos uns alienados. O escravo era totalmente alienado. Nós somos piores, porque nos alienamos a nós próprios. Há correntes que já se quebraram mas continuamos a transportá-las conosco, por medo de as deitarmos fora e depois nos sentirmos nus. (PEPETELA, 1982, p. 208) 
Vieram de nossa formação hábitos alienados e as formas culturais, tal como as formas políticas, sociais e econômicas, resistem. Há nelas, de um lado, uma experiência acumulada; e, de outro, implicações ideológicas que tendem a justificar hegemonias. Constituem desenhos ou linhas que resistem e determinam a formação de caracteres, com papéis sociais marcados. O grande problema, do ponto de vista político, é que tais impregnações fazem parte do cotidiano e configuram as expectativas de cada ator, dirigente ou dirigido. Tais gestos alienantes serão mais enfáticos na obra posterior, de Pepetela, quando focalizará criticamente a nova sociedade urbana de Angola. Se escreveu Mayombe, na ambiência da guerrilha, escreverá depois romances como Predadores, cujo título direcionado às esferas de poder econômico, já é ilustrativo por si mesmo.

A travessia, já apontamos, se fez para essa geração tendo como horizonte uma libertação nacional e social que criasse um "homem novo" - criativo, íntegro, sociável, inclinado ao bem coletivo. Não atingiu, para seus atores mais consequentes em relação ao seu ideário, seus maiores objetivos libertários. Impõem-se outras e novas travessias. Conseguiram libertar do colonialismo o país, mas muitas formas conservadoras, como hábitos estabelecidos, continuaram. O exercício de determinados papéis, conjugado a determinadas práxis, modelam os novos autores, com muitos dos caracteres contra os quais se colocaram. A travessia foi feita sem entretanto atingir-se o ponto sonhado. Não basta que o rio Kuanza - simbólico da unidade nacional - desemboque em Luanda, com fragmentos de todo o país em suas águas. Impõem-se reciprocidades, segundo a enunciação, para um encontro cidade-campo em que as margens do rio revelem essa integração psicossocial e econômica em sentido amplo. Não pode ser uma via simbólica de mão única.

\section{UTOPIA, DISTOPIA E A JUVENTUDE COMO PRINCÍPIO}

Impõem-se, na atualidade, novas travessias, talvez com novos atores, que a enunciação parece apontar de forma ainda tênue. Há uma atmosfera de pessimismo, que uma das personagens mais otimistas vai contraditar. Vale aqui - deslocando o foco para Portugal e os participantes do movimento revolucionário do 25 de Abril, que pôs fim à ditadura salazarista - a transcrição do refrão da canção "O madrugar de um sonho", de Frederico de Brito, interpretada por Carlos do Carmo. Os sonhos são do movimento dos jovens capitães de Abril. Dessa revolução voltada para uma revolução social participaram os mesmos e outros jovens embalados por suas utopias, utopias correlatas àquelas sonhadas por jovens portugueses e africanos participantes da Casa, capítulo inicial deste romance: "Julguei ser um sonho/ Mas foi realidade/ E às vezes suponho/ Que não é verdade!/ Mas se alguém disser/ "Não" à liberdade/ Eu posso morrer/ Mas não é verdade".

A canção evidencia uma simetria de situações entre a revolução portuguesa e a dos países africanos colonizados por Portugal. Uma simetria 
supranacional, no âmbito de nossa comunidade cultural. Esse comunitarismo que nos aproxima, desenha inclinações que seriam extensíveis para outras situações, de quem viveu sonhos libertários, como em Angola. Em A geração da utopia esse sentido de solidariedade supranacional fez com que se reunissem participantes portugueses e angolanos na manifestação antiditatorial do $1^{\circ}$ de Maio. Solidariedade sob a sombra de um regime opressivo.

Importa hoje destacar o fato de que, após a euforia da tomada de poder e aparente conclusão da travessia libertária, constata-se que os pontos atingidos (tanto em Portugal como em Angola) não eram exatamente os previstos, mas a travessia não deixou de se efetivar. Só que não houve um epílogo histórico. Esses são os fluxos das águas da vida, que acabam por se abrir a novas travessias. Renova-se o giro da espiral da linha do tempo. No início da travessia um Viriato da Cruz escreveu o poema "Mamã Negra (Canto da Esperança)", numa perspectiva talvez neorromântica, em que vê as projeções dos olhos da Mãe (a mátria, a terra angolana), "cintilantemente firme - como a Esperança... /em nós outros, teus filhos,/ gerando, formando, anunciando -/ o dia da humanidade/O DIA DA HUMANIDADE”.

A tendência, quando esses sonhos não se concretizam integralmente como se desejava, é o estado de melancolia, ou a distopia entre os atores embalados pela plenitude da utopia. Entretanto, a vida social se move na direção da esperança. Acreditar que as coisas possam ser melhores do que são. Se a esperança não se configurar em torno de projetos imbuídos de um princípio de juventude, como o que embalou os atores dessa geração, outros atores poderão empunhar em proveito próprio essa inclinação de esperança, através da mistificação, como ocorre com o pensamento religioso. É o que aponta o romance $A$ geração da utopia, certamente num horizonte que não se restringe apenas a Angola.

A esperança misticamente associada assim ao prazer, nas dimensões estreitas do consumo imediato, em que o próprio corpo humano se transforma em mercadoria. A esperança, como energia da geração da utopia, funda-se num princípio de juventude, que independe da idade dos atores envolvidos e se volta para o futuro. Nesta mistificação da esperança, que se efetiva paralelamente às instâncias de estado, a vida não se move na perspectiva de futuro, mas de um desfrute voltado para um contínuo presente, de afirmação individualista. Olha-se de lado e não para frente. Não é mais a religiosidade de um paraíso perdido a ser reconquistado com sofrimento das religiões tradicionais, mas o mundo da mistificação de mercadorias, que entram na economia das trocas simbólicas, fundamentadas nas articulações socioeconômicas. Como se observa, centrado em Angola, A geração da utopia tem como matéria uma situação mais geral, que vem do mundo da desregulamentação do capitalismo financeiro, que chegou mesmo a proclamar o fim da história.

Outro problema que se coloca, como apontamos em vários momentos, é o da sobrevivência das formas que podem limitar os movimentos 
de toda uma geração, já que as águas da vida não têm um traçado definido, e é difícil seguir os sulcos na água de travessias anteriores, que não se repetirão, como podemos inferir do conhecido poema de Antonio Machado: "Caminhante, não há caminho,/faz-se caminho ao andar./Ao andar faz-se o caminho,/ e ao olhar-se para trás/ vê-se a senda que jamais/ se há-de voltar a pisar./ Caminhante, não há caminho,/ somente sulcos no mar."

Fica enfaticamente registrado, no romance A geração da utopia, como os modos de articulação que levam às formas tradicionais acabam por enredar o ser político da geração. Para Pepetela - depreendemos através de suas estratégias discursivas -, o otimismo que embalou a geração só poderia ser efetivo se imbuído de sentido crítico. É o que aparece na trajetória de Aníbal, que acaba por se impor registros mais distanciados, marcado por certa negatividade. São experiências que apontam para o processo, contínuo, que impõe uma dialética entre otimismo e distanciamento crítico, tendo em vista a necessidade de constantes redirecionamentos de trajetórias, pois o "mundo do rio não é o mundo da ponte", relembremos.

Não há fórmulas feitas e nem palavras de ordens unívocas. Estas levam apenas a uma disciplina de caserna, refutada pela enunciação. Quando estas formulações aparecem no romance, são meramente ritualísticas, acabando por levar à repetição do mesmo. Talvez exatamente por isso, no "Epílogo", Pepetela fecha o seu romance indicando que não há uma conclusão definitiva numa história que começou com um "portanto". Consubstancia-se a efabulação, assim, mais uma vez, como um processo aberto, mas com horizontes, para que não se submeta aos movimentos hegemônicos de cursos estabelecidos. Nas águas da vida social, eivada da plenitude sonhada, há que enfrentar esses fluxos avassaladores. Ao atingir a margem que apontava para a descolonização, constatou-se que a travessia marcou a trajetória, levando a pontos diferentes, distantes da liberação sonhada. Um transcurso de uma geração que se dissocia, desconfigurando-se melancolicamente a energia, a potencialidade subjetiva, que a embalava. Uma desconstrução que não perde seu sentido dialético de processo, pois que não deixa Pepetela de constatar que os novos tempos formam tenuamente atores de uma nova geração, que certamente não deixará de se valer da experiência da geração anterior.

\section{REFERÊNCIAS BIBLIOGRÁFICAS}

PEPETELA. A geração da utopia. Lisboa: Publicações Dom Quixote, 1992.

. Mayombe. São Paulo: Editora Ática, 1982.

Recebido para publicação em 15/05/2013

Aprovado em 19/08/2013 